\title{
Ultraviolet and visible complex refractive indices of secondary organic material produced by photooxidation of the aromatic compounds toluene and $m$-xylene
}

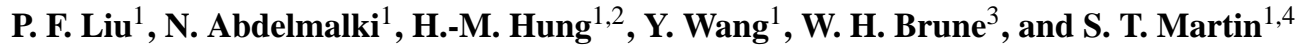 \\ ${ }^{1}$ School of Engineering and Applied Sciences, Harvard University, Cambridge, MA, USA \\ ${ }^{2}$ Department of Atmospheric Sciences, National Taiwan University, Taipei, Taiwan \\ ${ }^{3}$ Department of Meteorology, Pennsylvania State University, University Park, PA, USA \\ ${ }^{4}$ Department of Earth and Planetary Sciences, Harvard University, Cambridge, MA, USA
}

Correspondence to: S. T. Martin (scot_martin@harvard.edu)

Received: 24 July 2014 - Published in Atmos. Chem. Phys. Discuss.: 8 August 2014

Revised: 24 December 2014 - Accepted: 11 January 2015 - Published: 10 February 2015

\begin{abstract}
Secondary organic material (SOM) produced by the oxidation of anthropogenic volatile organic compounds can be light-absorbing (i.e., brown carbon). Spectral data of the optical properties, however, are scarce. The present study obtained the continuous spectra of the real and imaginary refractive indices $(m=n-i k)$ in the ultraviolet (UV)to-visible region using spectroscopic ellipsometry for $n$ and UV-visible spectrometry for $k$. Several different types of SOM were produced in an oxidation flow reactor by photooxidation of toluene and $m$-xylene for variable concentrations of nitrogen oxides $\left(\mathrm{NO}_{\mathrm{x}}\right)$. The results show that the $k$ values of the anthropogenically derived material were at least 10 times greater than those of the biogenically derived material. The presence of $\mathrm{NO}_{\mathrm{x}}$ was associated with the production of organonitrogen compounds, such as nitro-aromatics and organonitrates, which enhanced light absorption. Compared with the SOM derived from $m$-xylene, the toluenederived SOM had larger $k$ values, as well as a greater $\mathrm{NO}_{\mathrm{x}}-$ induced enhancement, suggesting different brown-carbonforming potentials of different aromatic precursor compounds. The results imply that anthropogenic SOM produced around urban environments can have an important influence on ultraviolet irradiance, which might consequently influence photochemical cycles of urban pollution.
\end{abstract}

\section{Introduction}

Aerosol particles affect many atmospheric processes. Globally, aerosol particles influence Earth's radiative balance both directly by scattering and absorbing solar radiation and indirectly by acting as cloud nuclei. At the urban and regional scale, aerosol particles contribute to the degradation of visibility (Chen et al., 2012) and adversely influence human health (Dockery et al., 1993). A major fraction of the ambient particle population is secondary organic material (SOM) produced by oxidation of anthropogenic and biogenic gaseous precursors (Kanakidou et al., 2005; Hallquist et al., 2009). The magnitude and properties of SOM, however, are still poorly represented in models (Heald et al., 2005; Volkamer et al., 2006).

Ultraviolet-absorbing components in atmospheric particles can significantly reduce ultraviolet (UV) irradiation, thus affecting photochemistry in the atmospheric boundary layer (Jacobson, 1999; Barnard et al., 2008). Modeling the optical properties and radiative effects, however, requires spectral data of complex refractive indices $(m=n-i k)$, including both the refractory index $n$ and the absorptive index $k$. Lack of this information, especially in the UV region (300$400 \mathrm{~nm}$ ), hampers an understanding of the photochemical effect of anthropogenic SOM.

In highly polluted urban regions, anthropogenic aromatic compounds constitute up to $70 \%$ of the non-methane hydrocarbons (Ran et al., 2012). Among the anthropogenic aromatics, toluene and xylenes are the most abundant compounds, 
and the yields for the production of SOM from these compounds are high (Odum et al., 1996, 1997; Ng et al., 2007; Hildebrandt et al., 2009; Zhang et al., 2014). Quantitative estimates of the climate effects of anthropogenic SOM, however, remain limited for several different reasons, including the incomplete knowledge of chemical composition and optical properties.

The gas- and particle-phase chemistry of aromatic oxidation is complex, and a broad spectrum of products is produced from the oxidation of a single precursor (Forstner et al., 1997; Jang and Kamens, 2001a). The concentration of nitrogen oxides $\left(\mathrm{NO}_{\mathrm{x}}\right)$ further influences the product distribution (Sato et al., 2007). Some of the molecular products resulting from the oxidation of aromatic precursors have been identified and quantified (Forstner et al., 1997; Cocker III et al., 2001; Jang and Kamens, 2001a; Hamilton et al., 2005; Sato et al., 2007). These products, however, typically constitute less than $50 \%$ of the reacted carbon (Forstner et al., 1997; Hamilton et al., 2005; Sato et al., 2007). Particle-phase reactions have been proposed as an important mechanism of SOM production from aromatic precursors, which may explain the uncharacterized components of aromatic-derived SOM (Jang and Kamens, 2001a; Jang et al., 2002; Kalberer et al., 2004).

The chemical complexity of SOM propagates into the optical properties. Recent studies have shown that different types of SOM have varying light-absorbing properties in the ultraviolet (UV) and visible regions of the electromagnetic spectrum (Nakayama et al., 2010; Lambe et al., 2013; Liu et al., 2013). Some types of SOM absorb light significantly in the UV-visible region and are then considered constituents of socalled "brown carbon" (Shapiro et al., 2009; Laskin et al., 2010; Updyke et al., 2012; Zarzana et al., 2012). In particular, several studies have pointed out that aromatic-derived SOM is an important class of UV absorbers. The investigated precursors have included phenolic catechol and guaiacol (Ofner et al., 2011; Lambe et al., 2013; Liu et al., 2013), polycyclic aromatic naphthalene (Lambe et al., 2013), and monocyclic toluene (Nakayama et al., 2010, 2013; Zhong and Jang, 2011; Zhong et al., 2012; Li et al., 2014).

In the present work, the spectroscopic complex refractive indices of several types of aromatic-derived SOM are measured using spectroscopic ellipsometry for $n$ (Liu et al., 2013) and UV-visible spectroscopy for $k$. The SOMs were produced from the photooxidation of toluene and $m$-xylene in an oxidation flow reactor, both in the absence of $\mathrm{NO}_{\mathrm{x}}$ (hereafter "low $\mathrm{NO}_{\mathrm{x}}$ "; $<70 \mathrm{ppt}$ ) and in the presence of $\mathrm{NO}_{\mathrm{x}}$ at different levels (hereafter "high $\mathrm{NO}_{\mathrm{x}}$ "). For the high- $\mathrm{NO}_{\mathrm{x}}$ experiments, the initial $\mathrm{NO}_{\mathrm{x}}$ concentration varied from 2.5 to $10 \mathrm{ppm}$, corresponding to initial hydrocarbon: $\mathrm{NO}_{\mathrm{x}}$ ratios of 3.5 to $16 \mathrm{ppbC} \mathrm{ppbN}^{-1}$. In complement to the optical measurements, the chemical composition was characterized by the infrared spectroscopy. The paper concludes with a case study of light-absorbing particles in an urban plume. Based on the calculations using a Mie-theory-based optical model, possible radiative effects of brown carbon from anthropogenically derived SOMs are discussed.

\section{Experimental}

\subsection{Production of secondary organic material}

Toluene (EMD Chemicals, $\geq 99.8 \%$ ) and $m$-xylene (Sigma Aldrich, $\geq 99 \%$ ) were continuously injected by a syringe pump (Chemyx, Fusion 200) into a glass round-bottom flask (Ace glass, $100 \mathrm{~mL}$ ). The flask was held at $310 \mathrm{~K}$, and the organic liquids vaporized at the tip of a syringe prior to the formation of a falling drop. The resulting gas-phase molecules were swept in a flow of pure air (Aadco 737 Pure Air Generator; $1.0 \mathrm{~L} \mathrm{~min}^{-1}$ ) into an oxidation flow reactor (OFR). The injected precursor concentration was $5.0 \pm 0.5 \mathrm{ppm}$, which was calculated from the injection rate of the liquid into the flow rate of the reactor.

Aerosol particles composed of secondary organic material were produced in the oxidation flow reactor (Kang et al., 2007; Lambe et al., 2011). Aromatic precursors were oxidized by hydroxyl radicals $(\mathrm{OH})$ (Fig. 1), and some of the resulting low-volatility products contributed to new particle production in the OFR. The experimental conditions are listed in Table 1. The OFR was operated at a temperature of $293 \pm 2 \mathrm{~K}$, a flow rate of $7.0 \pm 0.1 \mathrm{~L} \mathrm{~min}^{-1}$, and a residence time of $110 \pm 2 \mathrm{~s}$. Hydroxyl radicals were produced by photochemical reactions involving ozone and water inside the OFR as follows: (i) $\mathrm{O}_{3}+h v(254 \mathrm{~nm}) \rightarrow \mathrm{O}_{2}+\mathrm{O}\left({ }^{1} \mathrm{D}\right)$ followed by (ii) $\mathrm{O}\left({ }^{1} \mathrm{D}\right)+\mathrm{H}_{2} \mathrm{O} \rightarrow 2 \mathrm{OH}$. Ozone was generated outside the reactor by irradiating pure air with the ultraviolet emissions of a mercury lamp $(\lambda=185 \mathrm{~nm})$. The injected ozone concentration was $13 \pm 2 \mathrm{ppm}$. Water vapor was introduced by bubbling ultrapure water $(18.2 \mathrm{M} \Omega-\mathrm{cm})$ with air. The relative humidity inside the reactor was $13 \pm 3 \%$.

The experiments were conducted for several different concentrations of $\mathrm{NO}_{\mathrm{x}}$. For "low $\mathrm{NO}_{\mathrm{x}}$ " experiments, no $\mathrm{NO}_{\mathrm{x}}$ was added, and the nitric oxide (NO) concentration in the pure air was below the detection limit of the $\mathrm{NO}_{\mathrm{x}}$ analyzer (Eco Physics CLD $899 \mathrm{Y}$; < 70 ppt $\mathrm{NO}_{\mathrm{x}}$ ). For "high $\mathrm{NO}_{\mathrm{x}}$ " experiments, $\mathrm{NO}$ of 2.5 to $10 \mathrm{ppm}$ was injected using a mass flow controller (Table 1). In a control experiment to assess the possible importance of ozonolysis, in the dark the produced particle mass concentration was $0.1 \%$ of that obtained when the ultraviolet lamps were illuminated, indicating that photooxidation was the major pathway of SOM production.

\subsection{Spectroscopic ellipsometry}

Spectroscopic ellipsometry of SOM films followed the procedures introduced in Liu et al. (2013). Thin, continuous, mirror-like films of SOM were synthesized by electrostatic deposition of aerosol particles onto silicon substrates. Information about film preparation and characterization was provided in Liu et al. (2013). Spectroscopic ellipsometry 
Table 1. Experimental conditions, infrared band areas of organonitrogen groups normalized by the area of alkane bands, and complex refractive indices of the studied SOMs.

\begin{tabular}{|c|c|c|c|c|c|c|c|c|c|c|c|}
\hline & \multirow[t]{2}{*}{ Precursor } & \multirow[t]{2}{*}{$\begin{array}{l}\mathrm{HC}_{0} \\
(\mathrm{ppm})\end{array}$} & \multirow[t]{2}{*}{$\begin{array}{l}\mathrm{NO}_{0} \\
(\mathrm{ppm})\end{array}$} & \multirow[t]{2}{*}{$\begin{array}{c}\mathrm{HC}_{0} / \mathrm{NO}_{0} \\
\left(\mathrm{ppbC} \mathrm{ppbN}^{-1}\right)\end{array}$} & \multirow{2}{*}{$\begin{array}{l}\text { Particle mass } \\
\text { concentration } \\
\left(\mu \mathrm{g} \mathrm{m}^{-3}\right)^{\mathrm{a}}\end{array}$} & \multicolumn{2}{|c|}{$\begin{array}{l}\text { Infrared band } \\
\text { area ratio }^{b}\end{array}$} & \multicolumn{2}{|c|}{$320 \mathrm{~nm}$} & \multicolumn{2}{|c|}{$405 \mathrm{~nm}$} \\
\hline & & & & & & $\begin{array}{c}A_{-\mathrm{NO}_{2}} / \\
A_{\mathrm{C}-\mathrm{H}}\end{array}$ & $\begin{array}{c}A_{-\mathrm{ONO}_{2}} / \\
A_{\mathrm{C}-\mathrm{H}}\end{array}$ & $n$ & $k\left(\times 10^{3}\right)$ & $n$ & $k\left(\times 10^{3}\right)$ \\
\hline A1 & toluene & 5.0 & 0.0 & $\mathrm{n} / \mathrm{a}$ & $(2.08 \pm 0.17) \times 10^{3}$ & 0.00 & 0.00 & $1.567 \pm 0.008$ & $11 \pm 1$ & $1.546 \pm 0.004$ & $1.7 \pm 0.2$ \\
\hline $\mathrm{A} 2$ & toluene & 5.0 & 2.5 & 14 & $(1.84 \pm 0.16) \times 10^{3}$ & 0.46 & 0.79 & $1.570 \pm 0.007$ & $22 \pm 2$ & $1.552 \pm 0.004$ & $4.1 \pm 0.5$ \\
\hline A3 & toluene & 5.0 & 5.0 & 7.0 & $(1.37 \pm 0.15) \times 10^{3}$ & 0.94 & 2.11 & $1.585 \pm 0.007$ & $26 \pm 2$ & $1.562 \pm 0.005$ & $6.6 \pm 0.6$ \\
\hline A4 & toluene & 5.0 & 10.0 & 3.5 & $(0.77 \pm 0.13) \times 10^{3}$ & 1.47 & 2.68 & $1.591 \pm 0.009$ & $33 \pm 4$ & $1.571 \pm 0.005$ & $15.3 \pm 1.6$ \\
\hline B1 & $m$-xylene & 5.0 & 0.0 & $\mathrm{n} / \mathrm{a}$ & $(2.75 \pm 0.10) \times 10^{3}$ & 0.00 & 0.00 & $1.554 \pm 0.011$ & $7 \pm 1$ & $1.531 \pm 0.006$ & $0.8 \pm 0.1$ \\
\hline B2 & $m$-xylene & 5.0 & 2.5 & 16 & $(2.81 \pm 0.13) \times 10^{3}$ & 0.22 & 0.78 & $1.558 \pm 0.006$ & $10 \pm 1$ & $1.535 \pm 0.004$ & $1.2 \pm 0.3$ \\
\hline B3 & $m$-xylene & 5.0 & 5.0 & 8.0 & $(1.67 \pm 0.10) \times 10^{3}$ & 0.46 & 1.65 & $1.578 \pm 0.012$ & $11 \pm 1$ & $1.549 \pm 0.006$ & $1.6 \pm 0.2$ \\
\hline B4 & $m$-xylene & 5.0 & 10.0 & 4.0 & $(0.84 \pm 0.10) \times 10^{3}$ & 0.94 & 2.66 & $1.589 \pm 0.008$ & $15 \pm 1$ & $1.565 \pm 0.007$ & $3.0 \pm 0.3$ \\
\hline
\end{tabular}

${ }^{\mathrm{a}}$ Values are shown as (mean \pm 1 standard deviation) during the sampling periods. ${ }^{\mathrm{b}} A_{-\mathrm{NO}_{2}}$ represents the area of $-\mathrm{NO}_{2}$ band at $1558 \mathrm{~cm}^{-1} ; A_{-\mathrm{ONO}}$ represents the area of $-\mathrm{ONO}_{2}$ band at $1647 \mathrm{~cm}{ }^{-1} ;$ and $A_{\mathrm{C}-\mathrm{H}}$ represents the area of $\mathrm{C}-\mathrm{H}$ bands from 2790 to $2980 \mathrm{~cm}^{-1}$.

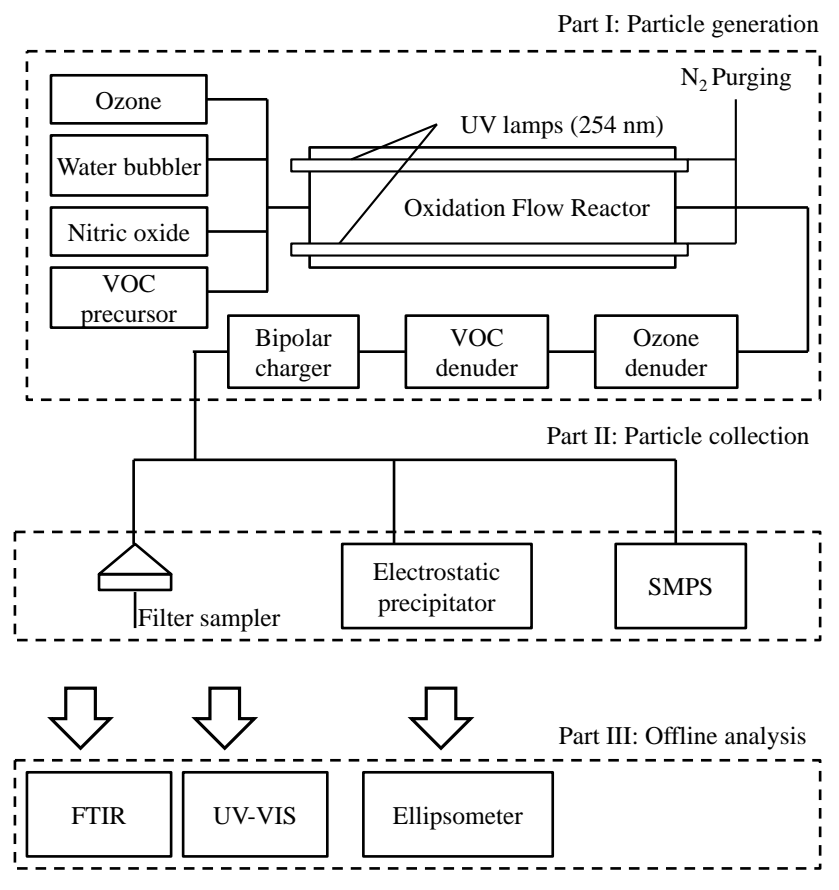

Figure 1. Schematic diagram of experimental apparatus. (I) Production of secondary organic material in aerosol form. (II) Sampling of particles onto a Teflon filter and growth of a thin film by electrostatic precipitation of particles onto a silicon substrate. (III) Fourier transform infrared spectroscopy (FTIR), ultraviolet-visible spectroscopy (UV-VIS), and spectroscopic ellipsometry of collected secondary organic material.

was carried out across 280 to $1200 \mathrm{~nm}$ at different incident angles using a variable-angle spectroscopic ellipsometer (J.A. Woollam VASE). From the data sets, film thickness, film non-uniformity, and wavelength-dependent real refractive indices, represented by $n$, were retrieved using the WVASE32 software package (J.A. Woollam VASE). Individual film thickness ranged from 100 to $350 \mathrm{~nm}$. The nonuniformity in film thickness was 5 to $10 \%$ over the ellipso- metric sampling spot. An absence of systematic error in retrieved refractive indices, as related to film thickness or film non-uniformity, was confirmed previously (Liu et al., 2013).

For each thin film sample, duplicate measurements were conducted at two or more different spots. The retrieved $n$ values agreed with each other within an absolute difference of 0.015 . An overall uncertainty of $n$, taking both the reproducibility and the fitting error into account, was within \pm 0.015 (10 and $90 \%$ confidence interval) across the studied wavelength range from 280 to $1200 \mathrm{~nm}$. As a confirmation of the overall approach, the $n$ values retrieved for squalane, a non-absorbing standard, and nigrosin dye, a light-absorbing standard, were consistent with literature values (cf. supporting information in Liu et al., 2013).

\subsection{Ultraviolet-visible spectroscopy}

Particles were collected onto Teflon filters (Millipore FGLP, $0.2 \mu \mathrm{m}$ pore size). The collected SOM mass was determined by weighing the filter before and after sample collection using an analytical balance (Sartorius, LA120S; 2.0 to $10.0 \mathrm{mg}$, with an uncertainty of $0.1 \mathrm{mg}$ ). The filters were extracted in methanol ( 40.0 to $100.0 \mathrm{~mL}$ ) while ultrasonicating (Branson $2510 ; 20 \mathrm{~min})$. The concentration $c$ was calculated from the measured SOM mass and the volume of the solvent. An extraction efficiency of $100 \%$ was assumed (Updyke et al., 2012). The extract was pipetted into a quartz cuvette having an optical length of $10 \mathrm{~mm}$. Absorbance spectra were recording using an ultraviolet-visible spectrometer (Agilent Model 8453). The spectrum of neat methanol was used as baseline. Analysis of blank filters showed no absorbance across the studied region of 240 to $800 \mathrm{~nm}$.

The imaginary refractive indices $k$ were calculated from the data sets as follows (Sun et al., 2007):

$k=\frac{\ln (10)}{4 \pi} \frac{\rho \lambda}{c L} A(\lambda)$

for an absorbance $A$, an optical path length $L(\mathrm{~m})$, a material density $\rho\left(\mathrm{kg} \mathrm{m}^{-3}\right)$, and a concentration $c\left(\mathrm{~kg} \mathrm{~m}^{-3}\right)$. 
A material density of $(1.4 \pm 0.1) \times 10^{3} \mathrm{~kg} \mathrm{~m}^{-3}$ was used in the analysis for toluene- and $m$-xylene-derived SOMs $(\mathrm{Ng}$ et al., 2007). For Suwannee River fulvic acid (International Humic Substances Society, 2S101F), a material density of $1.3 \times 10^{3} \mathrm{~kg} \mathrm{~m}^{-3}$ was used. For the $k$ values derived from UV-visible spectroscopy, propagation of uncertainties in $\rho$, $c$, and $A(\lambda)$ leads to an overall uncertainty of $\pm 15 \%$ (10 and $90 \%$ confidence interval) for $\lambda<420 \mathrm{~nm}$.

In an alternative to the UV-visible spectroscopy, the $k$ values are also retrieved by ellipsometry (Liu et al., 2013). A comparison of $k$ values derived from UV-visible spectroscopy and to those from ellipsometry is provided in the supporting information (cf. Fig. S1 in the Supplement). Overall agreement is good. For the smallest $k$ values $(<0.005)$, the ellipsometry retrievals have uncertainties approaching $>50 \%$. The uncertainties for UV-visible spectroscopy are considerably smaller $(<15 \%)$. Even so, this method requires sample extraction, and artifacts associated with extraction efficiency, material density, and solvent effect can be introduced. All factors considered, the $k$ values derived from UVvisible spectroscopy were adopted in this study for further analysis.

\subsection{Infrared spectroscopy}

Aerosol particles were collected on Teflon filters (Sartorius Stem, $0.2 \mu \mathrm{m}$ ) at a flow rate of $2 \mathrm{~L} \mathrm{~min}^{-1}$ for up to $24 \mathrm{~h}$. The collected mass on the filters ranged from 0.8 to $2.0 \mathrm{mg}$. The Teflon filter was cut to the shape of the germanium element of an attenuated total reflectance (ATR) accessory (Pike Technologies). The assembly was then screw-pressed to the crystal surface, the holder was opened, and the filter was peeled off. A thin layer of secondary organic material remained on the surface of the crystal (Hung et al., 2012). An experiment using a blank filter showed no residual signal from the Teflon filter after peeling. This preparation method avoided interference from Teflon filters across $900-1250 \mathrm{~cm}^{-1}$ (Russell et al., 2009b, 2011; Takahama et al., 2012), which otherwise obscured the absorption bands of $\mathrm{C}-\mathrm{O}$ stretching.

After preparation, the filter samples were taken for spectroscopy analysis. Infrared spectra were recorded using the ATR accessory in a Fourier transform infrared spectrometer (FTIR, Nicolet 670). The spectral resolution was $0.5 \mathrm{~cm}^{-1}$. The number of scans was 16. Additional information about the ATR-FTIR protocols is provided in Hung et al. (2012). A band fitting algorithm, implemented in MATLAB, was used to analyze the infrared spectra. The algorithm was adopted from Russell et al. (2009a) and Takahama et al. (2012). The absorption bands of alkanes $(\mathrm{C}-\mathrm{H})$, carboxylic hydroxyls $(\mathrm{O}-\mathrm{H})$, alcoholic hydroxyls $(\mathrm{O}-\mathrm{H})$, and carbonyls $(\mathrm{C}=\mathrm{O})$ were identified using the literature-described algorithm. The algorithm was further developed in the present study to characterize nitrate $\left(-\mathrm{ONO}_{2}\right)$, nitro $\left(-\mathrm{NO}_{2}\right)$, and ether $(\mathrm{C}-\mathrm{O}-\mathrm{C})$ groups.

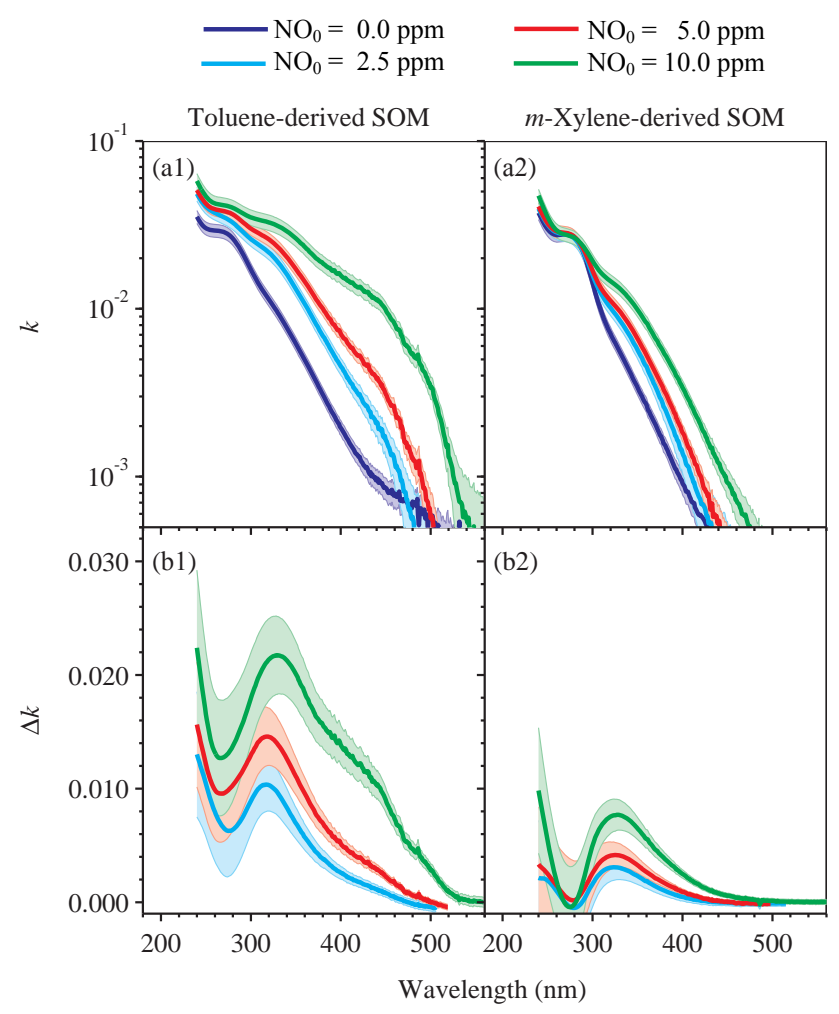

Figure 2. Absorptive component $k$ of the refractive indices of (column 1) toluene-derived SOMs and (column 2 ) $m$-xylene-derived SOMs for several different initial NO concentrations. Row 1 shows the $k$ values, and row 2 shows $\Delta k$ values (i.e., $\Delta k=k-k_{\mathrm{NO}_{0}=0}$ ). The $k$ values are derived from UV-Vis measurements (see main text). The shaded regions show confidence intervals of 10 to $90 \%$, as calculated by propagation of individual uncertainties for the parameters of Eq. (1).

\section{Results and discussion}

\subsection{Optical properties of aromatic-derived SOMs and the effect of $\mathrm{NO}_{\mathrm{x}}$}

The wavelength-dependent absorptive component $k$ of the refractive index is plotted in Fig. 2a for toluene- and $m$ xylene-derived SOMs prepared at several different initial NO concentrations (cf. Table S1 in the Supplement for tabulated data). The $k$ values increase with increasing initial NO concentration. For toluene-derived SOMs, the $k$ values at $405 \mathrm{~nm}$ range from 0.0017 to 0.0153 . These values compare to a range of 0.0018 to 0.0072 reported by Nakayama et al. (2013) for SOMs produced by toluene photooxidation in an environmental chamber.

The increase of $k$ for high $\mathrm{NO}_{\mathrm{x}}$ can in part be explained by the production of light-absorptive organonitrogen compounds, mostly nitro-aromatic compounds, such as nitrophenols, nitrocatechols, and dinitrophenols (cf. Sect. 3.2). These compounds have been identified as products from toluene photooxidation under high- $\mathrm{NO}_{\mathrm{x}}$ conditions (Forstner et al., 


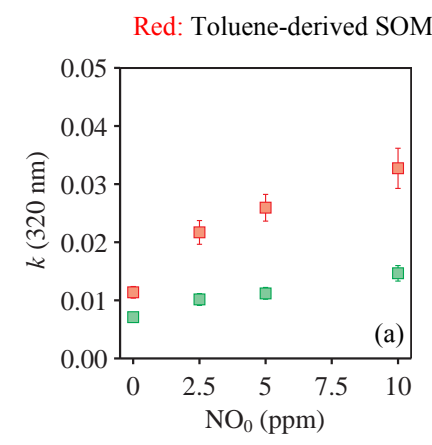

Green:: $m$-Xylene-derived SOM
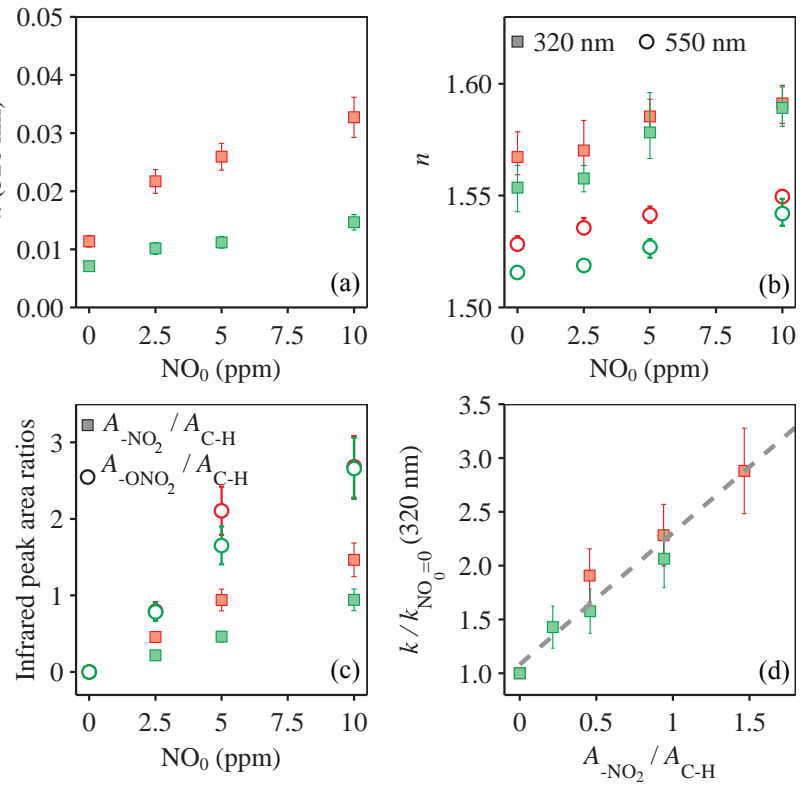

Figure 3. (a) Imaginary refractive indices $k$ at $320 \mathrm{~nm}$, (b) real refractive indices $n$ at 320 and $550 \mathrm{~nm}$, (c) the areas of nitro and nitrate absorption bands normalized by the area of alkane bands, all as a function of initial NO concentration. Shown in (d) is the ratio of $k / k_{\mathrm{NO}_{0}=0}$ as a function of the normalized area of nitro band $\left(A_{-\mathrm{NO}_{2}} / A_{\mathrm{C}-\mathrm{H}}\right)$, as drawn from (a) and (c). See also note $\mathrm{b}$ for Table 1 .

1997; Jang and Kamens, 2001b; Sato et al., 2007; Zhong et al., 2012; Nakayama et al., 2013). Nitro-aromatic compounds have also been identified in brown carbon sampled in urban plumes dominated by anthropogenic SOM (Zhang et al., 2011, 2013). The spectra for several methyl-nitrophenol isomers were measured (cf. Sect. S1 in the Supplement), and the results confirm that these compounds are strong UV absorbers. In particular, the aromatic compounds having hydroxyl and nitro groups in para substitution, such as 2-methyl-4-nitrophenol (a major product of aromatic photooxidation), have a strong absorption band at $320 \mathrm{~nm}$. Compounds having this configuration are good candidates for contribution to the main peak in the difference spectra $\Delta k$ (i.e., $\Delta k=k-k_{\mathrm{NO}_{0}=0}$ ) (Fig. 2b).

For similar reaction conditions, the $m$-xylene-derived SOMs are less absorptive than the toluene-derived SOMs (Fig. 3a; Table 1). The filter samples of toluene-derived SOMs have a yellowish to light brownish color, even for samples collected in low- $\mathrm{NO}_{\mathrm{x}}$ experiments. For comparison, $m$-xylene samples have a light yellowish color only for high$\mathrm{NO}_{\mathrm{x}}$ experiments and are visually white otherwise.

The $k$ values of the aromatic-derived SOMs can be compared to those of other light-absorbing material relevant to atmospheric aerosol particles (Fig. 4). The $k$ values decrease for increasing wavelength for the aromatic-derived SOMs. Similar wavelength-dependent behavior is observed for light-
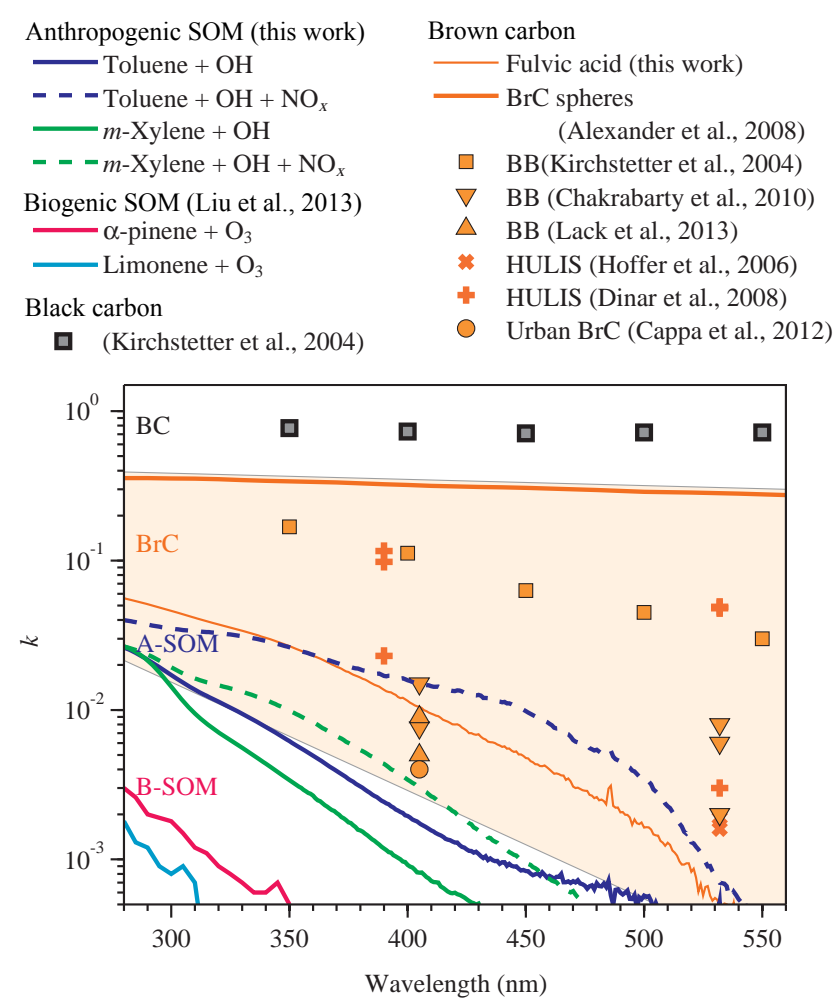

Figure 4. Comparison of wavelength-dependent $k$ values for different types of atmospherically relevant light-absorbing materials. This study: anthropogenic SOMs (A-SOM) derived from reacting toluene or $m$-xylene at low $\mathrm{NO}_{\mathrm{x}}\left(\mathrm{NO}_{0}=0 \mathrm{ppm}\right)$ and high $\mathrm{NO}_{\mathrm{x}}\left(\mathrm{NO}_{0}=10 \mathrm{ppm} ; \mathrm{HC}_{0} / \mathrm{NO}_{0}=3.5\right.$ and $4.0 \mathrm{ppbC} \mathrm{ppbN}^{-1}$ for toluene and $m$-xylene, respectively), and a brown carbon $(\mathrm{BrC})$ surrogate (Suwannee River fulvic acid). Literature: $\alpha$-pinene- and limonene-derived biogenic SOMs (B-SOM), various atmospheric $\mathrm{BrC}$ in both biomass burning (BB) and urban plumes, and black carbon (BC).

absorbing carbonaceous materials referred to as "brown carbon" in literature (Kirchstetter et al., 2004; Andreae and Gelencser, 2006; Hoffer et al., 2006; Alexander et al., 2008; Dinar et al., 2008; Chakrabarty et al., 2010; Cappa et al., 2012; Lack et al., 2013). In contradistinction, the value of $k$ for black carbon is independent of wavelength (Kirchstetter et al., 2004). Compared to the $k$ values of SOMs derived from examples of biogenic precursors (B-SOM), such as $\alpha$ pinene and limonene SOM (Liu et al., 2013), the $k$ values of the studied anthropogenic SOMs (A-SOM) are 1 order of magnitude more absorptive in the UV-visible region, even for those produced at low $\mathrm{NO}_{\mathrm{x}}$. These higher values suggest that conjugated double bonds are retained in some oxidation products, which have absorption transitions in the ultraviolet to near visible (Lambe et al., 2013). Even so, the $k$ values in the low- $\mathrm{NO}_{\mathrm{x}}$ experiments are smaller than those of a reference compound like Suwannee River fulvic acid, which is often cited as a surrogate of atmospheric humiclike substances (HULIS) (Gelencsér et al., 2003; Dinar et al., 


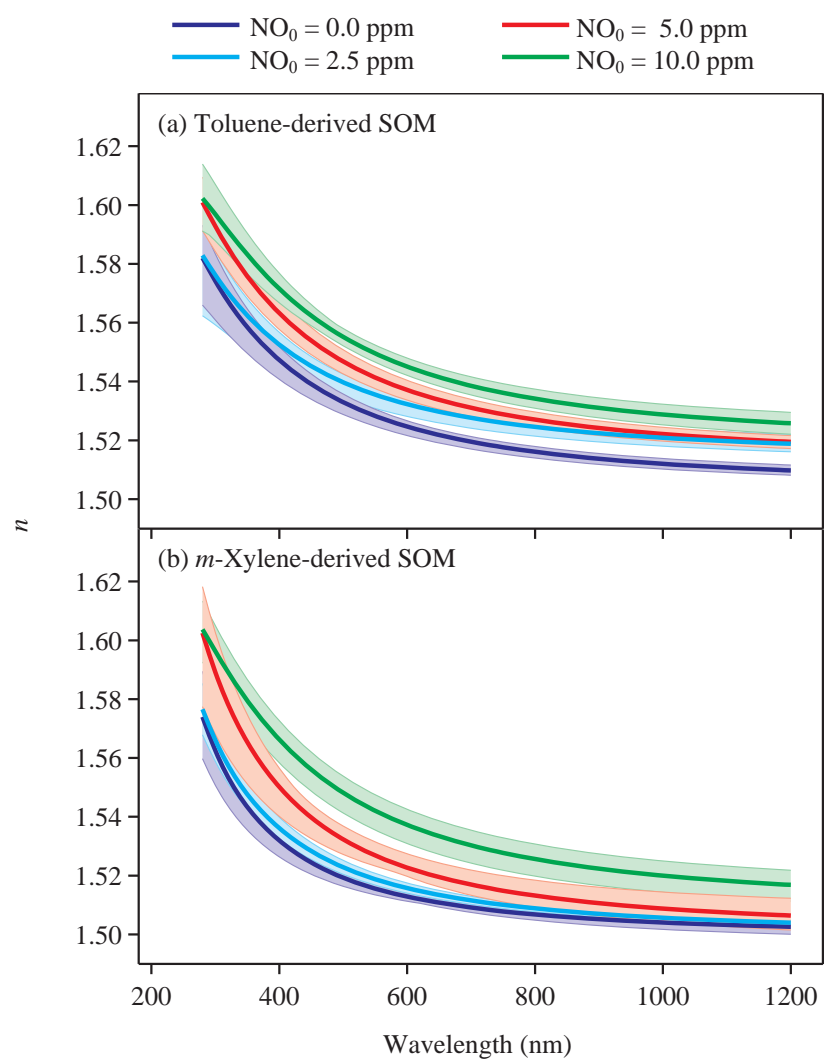

Figure 5. Real refractive indices $n$ of (a) toluene-derived SOMs and (b) $m$-xylene-derived SOMs for several different initial NO concentrations. The shaded regions represent confidence intervals of 10 to $90 \%$ for the ellipsometry analysis.

2006). In the high- $\mathrm{NO}_{\mathrm{x}}$ experiments, however, the $k$ values are within the range of atmospheric brown carbon (cf. shaded region in Fig. 4).

The real refractive indices $n$ of toluene- and $m$-xylenederived SOMs are shown in Fig. 5 for several different initial NO concentrations. The $n$ values decrease for increasing wavelength. The curves can be parameterized by the threeterm form of Cauchy's equation (cf. Table S2). The Cauchyform of the curves for the studied anthropogenic SOMs also holds for the biogenic SOMs reported previously (Liu et al., 2013).

The refractive indices $n$ shift +0.02 for both toluene- and $m$-xylene-derived SOMs for an increase of the initial NO concentration from 0 to $10 \mathrm{ppm}$ (Fig. 5). This upward shift of $n$ for increasing initial NO concentration is possibly attributed to an increasing abundance of nitrogen in the SOM produced at higher initial NO concentrations. Nitrogen has a higher atomic polarizability $\left(1.03 \AA^{3}\right)$ than both oxygen $\left(0.57 \AA^{3}\right)$ and hydrogen $\left(0.17 \AA^{3}\right)$ (Bosque and Sales, 2002). The $n$ value of a material is related to its polarizability by the Lorentz-Lorenz equation (Bosque and Sales, 2002). Within the tolerance of the measurement uncertainty, the $n$ values do not differ between SOMs derived from the two different aro- matic precursors at the same initial $\mathrm{NO}_{\mathrm{x}}$ concentration. The implication could be that the $n$ values of SOMs are mainly determined by bulk chemical properties, such as the elemental ratios or functional groups (cf. Sects. 3.2 and 3.3). Detailed chemical properties, such as the molecular structure, might play a minor role in determining the value of $n$. In this case, upscaling of the laboratory parameterizations to largescale models of the effects of different types of SOMs on radiative forcing and climate is simplified (Lambe et al., 2013; Flores et al., 2014; Kim et al., 2014). As a caveat, the SOMs of this study were produced at mass concentrations much higher than typical atmospheric concentrations. Both elemental composition and refractive index can depend on mass concentration (Shilling et al., 2009; Kim et al., 2012; Kim and Paulson, 2013), and further investigations are needed to quantify this possible effect.

\subsection{Production of organonitrogen compounds and light absorption}

The infrared spectra in the presence and absence of $\mathrm{NO}_{\mathrm{x}}$ are similar, except for organonitrogen groups, such as $-\mathrm{NO}_{2}$ and $-\mathrm{ONO}_{2}$ (Fig. 6). This similarity suggests that the oxygencontaining functional groups, excluding nitrogen-containing groups, are substantially similar for SOMs produced at the different $\mathrm{NO}_{\mathrm{x}}$ concentrations. SOMs derived from toluene and $m$-xylene also have similar overall compositions.

Organonitrogen compounds are detected in SOM collected in high- $\mathrm{NO}_{\mathrm{x}}$ experiments. The bands at 846, 1281, and $1647 \mathrm{~cm}^{-1}$, corresponding to organonitrate groups $\left(-\mathrm{ONO}_{2}\right)$, are present in both toluene- and $m$-xylene-derived SOMs (Roberts, 1990; Liu et al., 2012). The area of the $-\mathrm{ONO}_{2}$ band from 1610 to $1690 \mathrm{~cm}^{-1}$, when normalized by the alkane $\mathrm{C}-\mathrm{H}$ bands from 2790 to $2980 \mathrm{~cm}^{-1}$ to account for different masses on the filters, increases for greater initial NO concentrations (Fig. 3c). Comparison of the spectrum of the toluene-derived SOM to that of $m$-xylene-derived SOM for fixed initial $\mathrm{NO}_{\mathrm{x}}$ concentration shows that the $-\mathrm{ONO}_{2}$ fractions are approximately equal for both types of SOMs produced. The dominant mechanism for $-\mathrm{ONO}_{2}$ production, which is the reaction of peroxy radicals $\left(\mathrm{RO}_{2}\right)$ with $\mathrm{NO}$ (Roberts, 1990), can explain why the fraction of $-\mathrm{ONO}_{2}$ increases for greater $\mathrm{NO}$ concentrations.

In the high- $\mathrm{NO}_{\mathrm{x}}$ experiments, $-\mathrm{NO}_{2}$ groups are produced. For the toluene-derived SOM, the production of $-\mathrm{NO}_{2}$ groups is indicated by a strong band at $1558 \mathrm{~cm}^{-1}$ and a weak band at $1342 \mathrm{~cm}^{-1}$ (Fig. 6a). For $m$-xylene-derived SOM, only the strong band at $1558 \mathrm{~cm}^{-1}$ is observed (Fig. 6b). Based on an analysis of area ratios, the mole fraction of $-\mathrm{NO}_{2}$ groups in the $m$-xylene-derived $\mathrm{SOM}$ is 35 to $50 \%$ lower than that in the toluene-derived SOM for fixed initial $\mathrm{NO}_{\mathrm{x}}$ concentration (Fig. 3c). The production mechanism of $-\mathrm{NO}_{2}$ group has been proposed as the adduction of $-\mathrm{NO}_{2}$ to phenoxy radicals to produce nitrophenols (Forstner et al., 1997; Jang and Kamens, 2001b; Nakayama et al., 

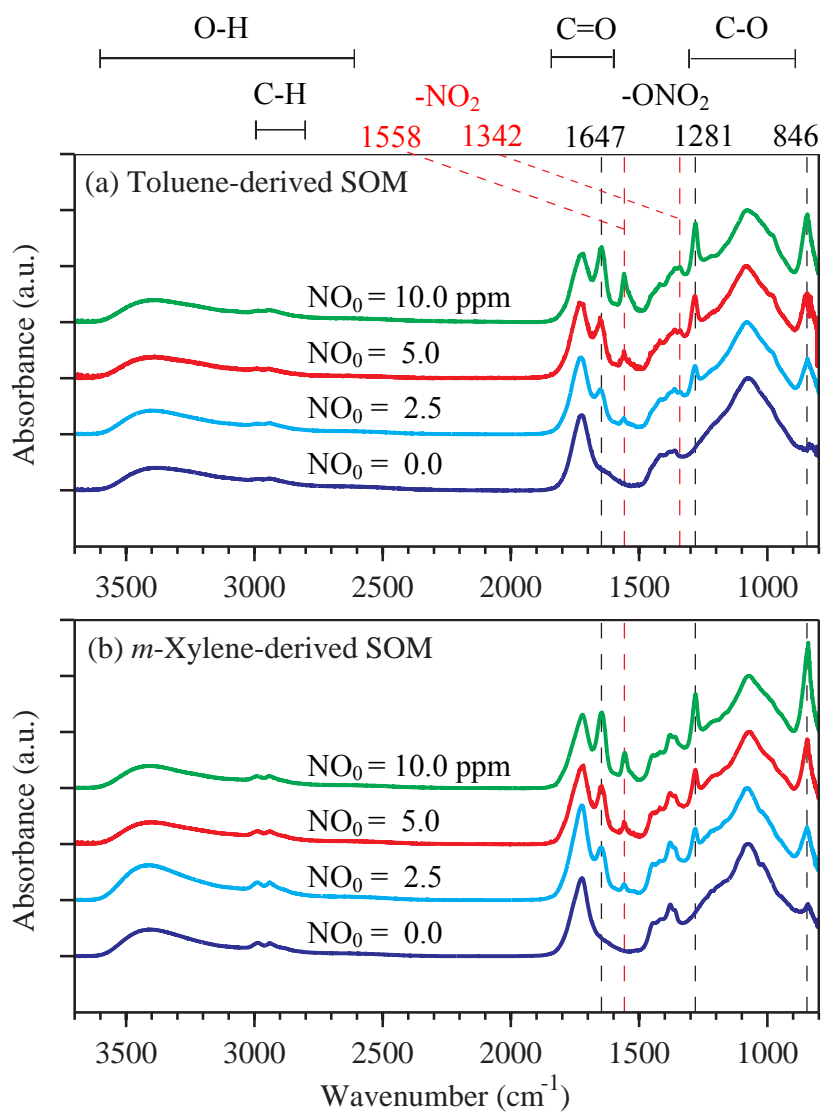

Figure 6. Infrared spectra of (a) toluene-derived SOMs and (b) $m$-xylene-derived SOMs for several different initial NO concentrations. Individual curves are offset from each other so that differences can be seen. Spectra are normalized to the peak height at $1100 \mathrm{~cm}^{-1}$, corresponding to a $\mathrm{C}-\mathrm{O}$ stretch, to compensate for different masses on the filter samples.

2013). Compared to toluene, the alkyl substitution at a metasite of $m$-xylene can inhibit the production of stable $-\mathrm{NO}_{2}$ adducts of phenoxy radicals (Nakayama et al., 2013), which can explain the lower $-\mathrm{NO}_{2}$ fraction observed for $m$-xylenederived SOM.

The difference in $-\mathrm{NO}_{2}$ fraction explains in part but not entirely the differences in $k$ values for toluene- compared to $m$-xylene-derived SOMs (cf. Sect. 3.1). When normalized by $-\mathrm{NO}_{2}$ fractions and for similar reaction conditions, $\Delta k$ at $320 \mathrm{~nm}$ for toluene-derived SOM is $50 \%$ higher than that of $m$-xylene-derived SOM. The implication is that the compounds in toluene-derived SOM are more UV-absorptive than those in $m$-xylene-derived SOM. Differences in the extent of conjugation of the oxygenated products can be important. The $k$ values in the UV region at low $\mathrm{NO}_{\mathrm{x}}\left(k_{\mathrm{NO}_{0}=0}\right)$ provide a baseline to quantify this influence. When normalized by both $k_{\mathrm{NO}_{0}=0}$ and $-\mathrm{NO}_{2}$ fraction, the two types of SOM are similarly absorptive (Fig. 3d). Organonitrogen groups attached to a conjugated chain can have increased light absorption as well as shifts in absorption to longer wavelengths.
SOM (this work)
$\square$ Toluene-derived SOM
O $m$-Xylene-derived SOM
Identified products (NIST)
$\triangleleft$ Toluene-derived SOM
(Forstner et al., 1997)
Reference compounds (NIST)
$\triangle$ Aldehydes
$\nabla$ Ketones
$\diamond$ Alcohols \& phenols
$\square$ Carboxylic acids
Ethers \& acetals

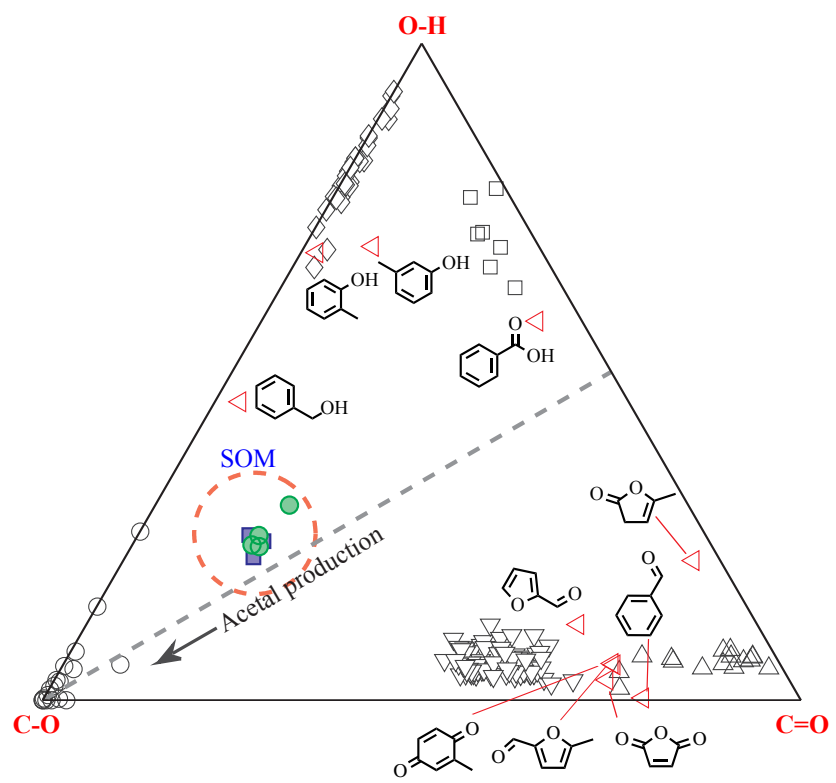

Figure 7. Ternary diagram representing the relative areas of $\mathrm{O}-\mathrm{H}$, $\mathrm{C}-\mathrm{O}$, and $\mathrm{C}=\mathrm{O}$ bands for aromatic-derived SOMs. Data for reference compounds in the NIST database, as well as of individual products reported in the literature for toluene-derived SOM, are also shown for comparison. The arrow illustrates the direction of particle-phase reactions. See Sect. S2 in the Supplement for further explanation of this diagram.

\subsection{Oxygenated groups and the importance of particle-phase reactions}

The infrared spectra show that several different types of oxygenated functional groups are present in the SOMs (Fig. 6). The groups include alcoholic hydroxyls $(\mathrm{O}-\mathrm{H})$ at $3100-3700 \mathrm{~cm}^{-1}$, carboxylic hydroxyls $(\mathrm{O}-\mathrm{H})$ at 2400 $3300 \mathrm{~cm}^{-1}$, carboxylic carbonyls $(\mathrm{C}=\mathrm{O})$, and mixed ketones / aldehydes $(\mathrm{C}=\mathrm{O})$ at $1640-1850 \mathrm{~cm}^{-1}$. The spectra of aromatic-derived SOMs are similar to those reported in the literature for related SOMs (Jang and Kamens, 2001a; Liu et al., 2012). The new finding of the present study is the presence of a strong $\mathrm{C}-\mathrm{O}$ stretch at $1000-1260 \mathrm{~cm}^{-1}$ (cf. Table S3). This band was obscured in previous studies by ammonium sulfate or Teflon filter. As explained for Fig. 7, this $\mathrm{C}-\mathrm{O}$ band cannot be explained by alcohols, phenols, cyclic anhydrides, carboxylic acids, or other carbonyls that have been identified as major products from oxidation reactions of aromatic precursors.

Figure 7 shows a ternary diagram representing the relative areas of $\mathrm{O}-\mathrm{H}, \mathrm{C}-\mathrm{O}$, and $\mathrm{C}=\mathrm{O}$ bands for toluene- and $m$ - 
Table 2. Parameters describing the different particle populations used in the case study of Sect. 3.4.

\begin{tabular}{|c|c|c|c|c|}
\hline \multirow[t]{2}{*}{ Type of particles } & \multicolumn{2}{|c|}{$\begin{array}{c}\text { Particle number- } \\
\text { diameter distribution }^{\mathrm{a}}\end{array}$} & \multirow{2}{*}{$\begin{array}{c}\text { Material } \\
\text { density } \\
\left(\mathrm{kg} \mathrm{m}^{-3}\right)\end{array}$} & \multirow[t]{2}{*}{ Complex refractive indices } \\
\hline & gmd (nm) & gsd & & \\
\hline $\begin{array}{l}\text { Brown carbon } \\
\text { toluene }+\mathrm{OH}+\mathrm{NO}_{\mathrm{x}}\end{array}$ & 100 & 1.8 & 1400 & $\begin{array}{l}\text { wavelength dependent } \\
\text { (this study })^{b}\end{array}$ \\
\hline$m$-xylene $+\mathrm{OH}+\mathrm{NO}_{\mathrm{x}}$ & 100 & 1.8 & 1400 & $\begin{array}{l}\text { wavelength dependent } \\
\text { (this study) }{ }^{\mathrm{c}}\end{array}$ \\
\hline Black carbon & 50 & 1.8 & 1800 & $1.85-0.71 i^{\mathrm{d}}$ \\
\hline Sulfate & 100 & 1.8 & 1770 & $1.53-0.00 i^{\mathrm{e}}$ \\
\hline
\end{tabular}

xylene-derived SOMs (cf. Sect. S2). Reference compounds having different types of oxygenated functional group are also plotted. The ternary diagram groups different types of oxygenated compounds into clusters. The individual products from photooxidation of toluene identified by gas chromatography/mass spectrometry (GC/MS) are plotted for comparison (Forstner et al., 1997). The cluster representing the toluene- and $m$-xylene-derived SOMs is uniquely situated and differentiated from the reference compounds because of the C-O stretch at $1000-1260 \mathrm{~cm}^{-1}$.

This absorption band at $1000-1260 \mathrm{~cm}^{-1}$ is plausibly contributed by an ether group (C-O-C) of acetals and hemiacetals produced via particle-phase reactions (Jang et al., 2002; Kroll and Seinfeld, 2008; Lim et al., 2010). These reactions tend to drive product distribution toward the $\mathrm{C}-$ $\mathrm{O}$ vertex of the composition diagram (cf. arrow in Fig. 7). The gas-phase oxidation of aromatic precursors produces dialdehydes in high yields, including glyoxal and methylglyoxal. These dialdehydes readily oligomerize along hemiacetal and acetal pathways, with associated changes in the $\mathrm{C}-$ $\mathrm{O} / \mathrm{C}=\mathrm{O}$ stretch band ratio (Loeffler et al., 2006). Hemiacetal / acetal production reactions leading to oligomerization can occur in SOM produced by photooxidation of trimethylbenzene (TMB), even in the absence of catalysis by sulfuric acid (Kalberer et al., 2004).

The mole fraction of each functional group is estimated using the absorptivity of Russell et al. (2009b) and Takahama et al. (2012), along with the area ratios of ether (C$\mathrm{O}-\mathrm{C})$ to alkane $(\mathrm{C}-\mathrm{H})$ bands for 19 ether and acetal compounds appearing in the NIST (National Institute of Standards and Technology) database. The analysis concludes that ether groups constitute up to $50 \%$ of the SOM mass. This result agrees with a modeling study suggesting that $20-80 \%$ of the SOM derived from toluene is produced by particle-phase reactions (Cao and Jang, 2009). These particle-phase reactions can produce oligomers having conjugated structures that contribute to the light absorption even in the absence of nitrogen moieties (Zhong et al., 2012).

\subsection{Atmospheric implications}

For the obtained spectral data sets of $n$ and $k$ (Sect. 3.1), the optical effects of brown carbon $(\mathrm{BrC})$ from anthropogenic SOM can be assessed. A model case study is formulated to represent light-absorbing particles in a fresh urban plume close to the anthropogenic sources. Parameters defining the case study are listed in Table 2. The case study considers a population of brown carbon particles produced by photooxidation of anthropogenic aromatic precursors in the presence of $\mathrm{NO}_{\mathrm{x}}$. This population is compared with populations of black carbon (BC) particles (representing emissions from fossil fuel combustion) and externally mixed at variable ratios with ammonium sulfate particles (representing the regional background atmospheric aerosol). The numberdiameter distributions of the $\mathrm{BrC}$ and sulfate particle populations are representative of polluted urban regions (Wu et al., 2008). The BC particle population having a relatively smaller mode diameter is typical for fresh soot particles emitted from motor vehicles (Kleeman et al., 2000). The investigated ratios of $\mathrm{BC}$ and ammonium sulfate are representative of Asian outflows (Ramana et al., 2010). The external mixing assumption is consistent with the small absorption enhancement of BC in urban regions (Cappa et al., 2012). The single-scattering albedo $\omega$, defined as the ratio of scattering to total extinction, is calculated for each population and their mixtures using a Mie-theory-based optical model (Bohren and Huffman, 1983; Liu et al., 2013) (Fig. 8a). The relative contribution of $\mathrm{BrC}$ absorption to total light absorption (i.e., $\mathrm{BrC} /(\mathrm{BrC}+\mathrm{BC})$ ) is calculated as a function of the mass ratio of organic matter to $\mathrm{BC}$. The calculated results for $\lambda=320,405$, and $550 \mathrm{~nm}$ are plotted in Fig. $8 \mathrm{~b}$. These three wavelengths are selected because solar radia- 

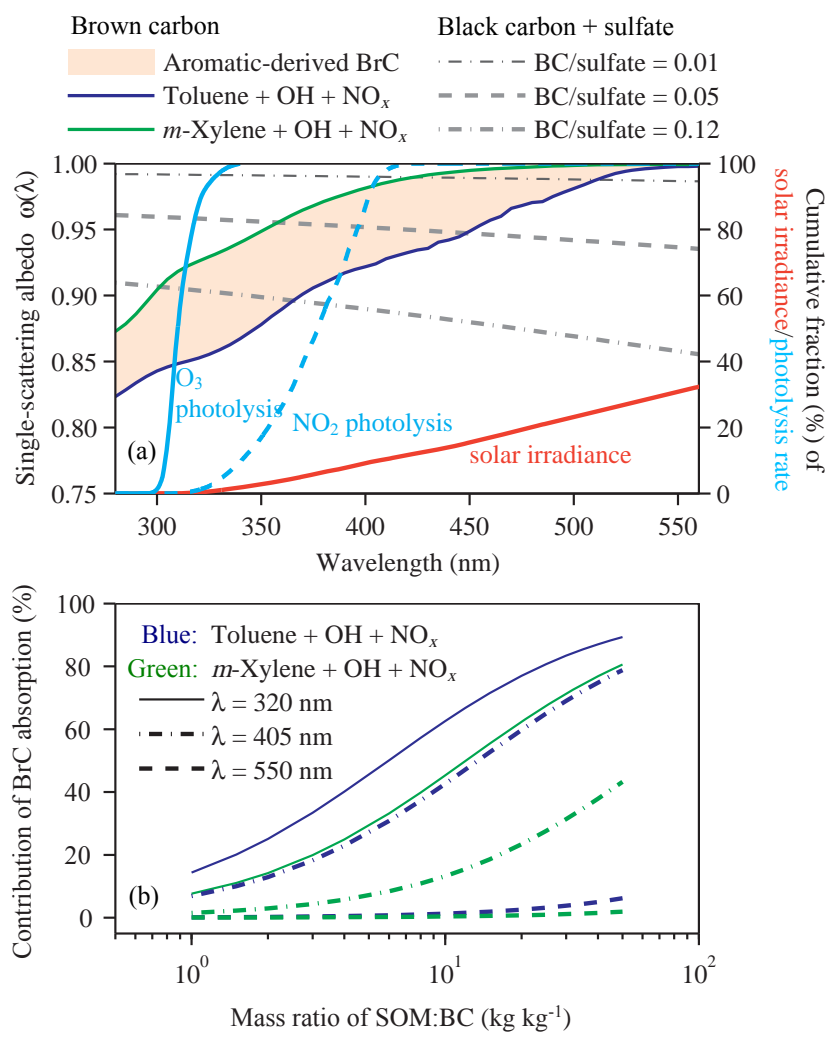

Figure 8. (a) Calculated single-scattering albedo of light absorbing particles for a scenario of an urban plume. Cumulative distributions for solar irradiance (orange) and photolysis rate coefficients (light blue) are also shown. The $k$ values of $\mathrm{BrC}$ were bounded by the cases for $m$-xylene $+\mathrm{OH}+\mathrm{NO}_{\mathrm{x}}\left(\mathrm{HC}_{0} / \mathrm{NO}_{0}=\right.$ $\left.4.0 \mathrm{ppbC} \mathrm{ppbN}^{-1}\right)$ and the toluene $+\mathrm{OH}+\mathrm{NO}_{\mathrm{x}}\left(\mathrm{HC}_{0} / \mathrm{NO}_{0}=\right.$

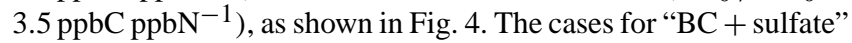
represent a $\mathrm{BC}$ population externally mixed with an ammonium sulfate population at variable mixing ratios representative of typical ambient values in a pollution plume (Ramana et al., 2010). Table 2 lists the physical parameters used for modeling the several different particle populations. The cumulative distributions were calculated for a standard solar spectrum of Air Mass 1.5 (http: //rredc.nrel.gov/solar/spectra/am1.5/). (b) Contribution of $\mathrm{BrC} \mathrm{ab-}$ sorption to total absorption as a function of the mass ratio of organic matter to black carbon. The $\mathrm{BrC}$ cases were the same as those shown in (a). External mixing of $\mathrm{BrC}$ and $\mathrm{BC}$ populations was assumed in the calculation.

tion in these bands respectively regulates $\mathrm{O}_{3}$ photolysis, $\mathrm{NO}_{2}$ photolysis, and energy balance (cf. Fig. 8a).

Results of the case study have several implications for climate and atmospheric chemistry modeling. The $\omega$ values of the $\mathrm{BrC}$ particle populations are close to unity for $\lambda>500 \mathrm{~nm}$ (Fig. 8a). When externally mixed with BC, the studied $\mathrm{BrC}$ has a negligible contribution to light absorption at $550 \mathrm{~nm}$ (Fig. 8b). These results indicate that these $\mathrm{BrC}$ populations have a net cooling effect. The $\omega$ values, however, decrease below unity for $\lambda<400 \mathrm{~nm}$, meaning that the particle population becomes absorptive in the UV region. Although the solar irradiance in the UV region contributes only $10 \%$ of the total solar irradiation, meaning a small heating effect by brown carbon for the conditions of the case study, the effect can still be important because UV irradiance determines the photolysis rates of many chemical species (Fig. 8a). For example, reduced UV irradiance for $\lambda<320 \mathrm{~nm}$ slows ozone photolysis, thus suppressing the production of $\mathrm{OH}$ radicals (Martin et al., 2003; Tie et al., 2003). The case study suggests that $\mathrm{BrC}$ populations can have a substantial contribution for light absorption in this band (Fig. 8b). For a mass ratio of organic matter to $\mathrm{BC}$ in a range of 2 to 20 , which is typical for urban atmosphere (Turpin et al., 1991), BrC accounts for $15-80 \%$ of the UV absorption at $320 \mathrm{~nm}$. The photolysis of $\mathrm{NO}_{2}$ is similarly suppressed by reduced UV irradiance for $\lambda<405 \mathrm{~nm}$, thus inhibiting the production of ozone (Dickerson et al., 1997; Martin et al., 2003). The implication is that, as an effective UV absorber, $\mathrm{BrC}$ influences the production of $\mathrm{O}_{3}$ and $\mathrm{OH}$ by reducing $\mathrm{UV}$ irradiance and consequently affects the oxidation capacity of the regional atmosphere.

In conclusion, photooxidation of toluene and $m$-xylene in the presence of $\mathrm{NO}_{\mathrm{x}}$ can produce SOMs having $k$ values similar to those reported for brown carbon in biomass burning and urban plumes (Kirchstetter et al., 2004; Hoffer et al., 2006; Alexander et al., 2008; Dinar et al., 2008; Chakrabarty et al., 2010; Cappa et al., 2012; Lack et al., 2013). The implication is that the photooxidation of anthropogenic precursors can be a significant source of atmospheric brown carbon. These findings are consistent with atmospheric observations in urban regions, such as the Los Angeles basin (Zhang et al., 2011, 2013; Cappa et al., 2012), Mexico City (Barnard et al., 2008), and Beijing (Cheng et al., 2011). The case studies considered in the present study suggest that anthropogenic brown carbon, along with brown carbon from biomass burning, can have a major influence on light absorption at wavelengths that drive photochemical reactions. This effect needs to be evaluated in the future modeling studies of atmospheric chemistry.

\section{The Supplement related to this article is available online at doi:10.5194/acp-15-1435-2015-supplement.}

Acknowledgements. This study was funded under NASA grant \#NNX12AG95G through the Radiation Science Program and NSF grant \#AGS-1244995. This work was performed in part at the Harvard Center for Nanoscale Systems (CNS), a member of the NSF National Nanotechnology Infrastructure Network (NNIN). Pengfei Liu acknowledges support from the NASA Earth and Space Science Fellowship Program. We thank the Vecitis Lab from Harvard University for providing a sample of the Suwannee River fulvic acid.

Edited by: A. Laskin 


\section{References}

Alexander, D. T. L., Crozier, P. A., and Anderson, J. R.: Brown carbon spheres in East Asian outflow and their optical properties, Science, 321, 833-836, doi:10.1126/science.1155296, 2008.

Andreae, M. O. and Gelencsér, A.: Black carbon or brown carbon? The nature of light-absorbing carbonaceous aerosols, Atmos. Chem. Phys., 6, 3131-3148, doi:10.5194/acp-6-3131-2006, 2006.

Barnard, J. C., Volkamer, R., and Kassianov, E. I.: Estimation of the mass absorption cross section of the organic carbon component of aerosols in the Mexico City Metropolitan Area, Atmos. Chem. Phys., 8, 6665-6679, doi:10.5194/acp-8-6665-2008, 2008.

Bohren, C. F. and Huffman, D. R.: Absorption and scattering of light by small particles, Wiley, New York, 530 pp., 1983.

Bond, T. C. and Bergstrom, R. W.: Light absorption by carbonaceous particles: an investigative review, Aerosol Sci. Tech., 40, 27-67, doi:10.1080/02786820500421521, 2006.

Bosque, R. and Sales, J.: Polarizabilities of solvents from the chemical composition, J. Chem. Inf. Comp. Sci., 42, 1154-1163, doi:10.1021/ci025528x, 2002.

Cao, G. and Jang, M.: An SOA model for toluene oxidation in the presence of inorganic aerosols, Environ. Sci. Technol., 44, 727733, doi:10.1021/es901682r, 2009.

Cappa, C. D., Onasch, T. B., Massoli, P., Worsnop, D. R., Bates, T. S., Cross, E. S., Davidovits, P., Hakala, J., Hayden, K. L., Jobson, B. T., Kolesar, K. R., Lack, D. A., Lerner, B. M., Li, S.-M., Mellon, D., Nuaaman, I., Olfert, J. S., Petäjä, T., Quinn, P. K., Song, C., Subramanian, R., Williams, E. J., and Zaveri, R. A.: Radiative absorption enhancements due to the mixing state of atmospheric black carbon, Science, 337, 1078-1081, doi:10.1126/science.1223447, 2012.

Chakrabarty, R. K., Moosmüller, H., Chen, L.-W. A., Lewis, K., Arnott, W. P., Mazzoleni, C., Dubey, M. K., Wold, C. E., Hao, W. M., and Kreidenweis, S. M.: Brown carbon in tar balls from smoldering biomass combustion, Atmos. Chem. Phys., 10, 63636370, doi:10.5194/acp-10-6363-2010, 2010.

Chen, J., Zhao, C. S., Ma, N., Liu, P. F., Göbel, T., Hallbauer, E., Deng, Z. Z., Ran, L., Xu, W. Y., Liang, Z., Liu, H. J., Yan, P., Zhou, X. J., and Wiedensohler, A.: A parameterization of low visibilities for hazy days in the North China Plain, Atmos. Chem. Phys., 12, 4935-4950, doi:10.5194/acp-12-4935-2012, 2012.

Cheng, Y., He, K.-B., Zheng, M., Duan, F.-K., Du, Z.-Y., Ma, Y.L., Tan, J.-H., Yang, F.-M., Liu, J.-M., Zhang, X.-L., Weber, R. J., Bergin, M. H., and Russell, A. G.: Mass absorption efficiency of elemental carbon and water-soluble organic carbon in Beijing, China, Atmos. Chem. Phys., 11, 11497-11510, doi:10.5194/acp11-11497-2011, 2011.

Cocker III, D. R., Mader, B. T., Kalberer, M., Flagan, R. C., and Seinfeld, J. H.: The effect of water on gas-particle partitioning of secondary organic aerosol: II. $m$-Xylene and 1,3,5trimethylbenzene photooxidation systems, Atmos. Environ., 35, 6073-6085, doi:10.1016/S1352-2310(01)00405-8, 2001.

Dickerson, R. R., Kondragunta, S., Stenchikov, G., Civerolo, K. L., Doddridge, B. G., and Holben, B. N.: The impact of aerosols on solar ultraviolet radiation and photochemical smog, Science, 278, 827-830, doi:10.1126/science.278.5339.827, 1997.

Dinar, E., Abo Riziq, A., Spindler, C., Erlick, C., Kiss, G., and Rudich, Y.: The complex refractive index of atmospheric and model humic-like substances (HULIS) retrieved by a cavity ring down aerosol spectrometer (CRD-AS), Faraday Discuss., 137, 279-295, doi:10.1039/b703111d, 2008.

Dinar, E., Mentel, T. F., and Rudich, Y.: The density of humic acids and humic like substances (HULIS) from fresh and aged wood burning and pollution aerosol particles, Atmos. Chem. Phys., 6, 5213-5224, doi:10.5194/acp-6-5213-2006, 2006.

Dockery, D. W., Pope, C. A., Xu, X., Spengler, J. D., Ware, J. H., Fay, M. E., Ferris, B. G., and Speizer, F. E.: An association between air pollution and mortality in six U.S. cities, New. Engl. J. Med., 329, 1753-1759, doi:10.1056/NEJM199312093292401, 1993.

Flores, J. M., Zhao, D. F., Segev, L., Schlag, P., Kiendler-Scharr, A., Fuchs, H., Watne, Å. K., Bluvshtein, N., Mentel, Th. F., Hallquist, M., and Rudich, Y.: Evolution of the complex refractive index in the UV spectral region in ageing secondary organic aerosol, Atmos. Chem. Phys., 14, 5793-5806, doi:10.5194/acp14-5793-2014, 2014.

Forstner, H. J. L., Flagan, R. C., and Seinfeld, J. H.: Secondary organic aerosol from the photooxidation of aromatic hydrocarbons: molecular composition, Environ. Sci. Technol., 31, 1345-1358, doi:10.1021/es9605376, 1997.

Gelencsér, A., Hoffer, A., Kiss, G., Tombácz, E., Kurdi, R., and Bencze, L.: In-situ formation of light-absorbing organic matter in cloud water, J. Atmos. Chem., 45, 25-33, doi:10.1023/a:1024060428172, 2003.

Hallquist, M., Wenger, J. C., Baltensperger, U., Rudich, Y., Simpson, D., Claeys, M., Dommen, J., Donahue, N. M., George, C., Goldstein, A. H., Hamilton, J. F., Herrmann, H., Hoffmann, T., Iinuma, Y., Jang, M., Jenkin, M. E., Jimenez, J. L., Kiendler-Scharr, A., Maenhaut, W., McFiggans, G., Mentel, Th. F., Monod, A., Prévôt, A. S. H., Seinfeld, J. H., Surratt, J. D., Szmigielski, R., and Wildt, J.: The formation, properties and impact of secondary organic aerosol: current and emerging issues, Atmos. Chem. Phys., 9, 5155-5236, doi:10.5194/acp-9-51552009, 2009.

Hamilton, J. F., Webb, P. J., Lewis, A. C., and Reviejo, M. M.: Quantifying small molecules in secondary organic aerosol formed during the photo-oxidation of toluene with hydroxyl radicals, Atmos. Environ., 39, 7263-7275, 2005.

Heald, C. L., Jacob, D. J., Park, R. J., Russell, L. M., Huebert, B. J., Seinfeld, J. H., Liao, H., and Weber, R. J.: A large organic aerosol source in the free troposphere missing from current models, Geophys. Res. Lett., 32, L18809, doi:10.1029/2005GL023831, 2005.

Hildebrandt, L., Donahue, N. M., and Pandis, S. N.: High formation of secondary organic aerosol from the photo-oxidation of toluene, Atmos. Chem. Phys., 9, 2973-2986, doi:10.5194/acp-92973-2009, 2009.

Hoffer, A., Gelencsér, A., Guyon, P., Kiss, G., Schmid, O., Frank, G. P., Artaxo, P., and Andreae, M. O.: Optical properties of humic-like substances (HULIS) in biomass-burning aerosols, Atmos. Chem. Phys., 6, 3563-3570, doi:10.5194/acp-6-3563-2006, 2006.

Hung, H.-M., Chen, Y.-Q., and Martin, S. T.: Reactive aging of films of secondary organic material studied by infrared spectroscopy, J. Phys. Chem. A, 117, 108-116, doi:10.1021/jp309470z, 2012.

Jacobson, M. Z.: Isolating nitrated and aromatic aerosols and nitrated aromatic gases as sources of ultraviolet light absorption, J. Geophys. Res., 104, 3527-3542, doi:10.1029/1998JD100054, 1999. 
Jang, M. S. and Kamens, R. M.: Characterization of secondary aerosol from the photooxidation of toluene in the presence of $\mathrm{NO}_{\mathrm{x}}$ and 1-propene, Environ. Sci. Technol., 35, 3626-3639, doi:10.1021/es010676+, 2001a.

Jang, M. S. and Kamens, R. M.: Atmospheric secondary aerosol formation by heterogeneous reactions of aldehydes in the presence of a sulfuric acid aerosol catalyst, Environ. Sci. Technol., 35, 4758-4766, doi:10.1021/es010790s, 2001b.

Jang, M. S., Czoschke, N. M., Lee, S., and Kamens, R. M.: Heterogeneous atmospheric aerosol production by acidcatalyzed particle-phase reactions, Science, 298, 814-817, doi:10.1126/science.1075798, 2002.

Kalberer, M., Paulsen, D., Sax, M., Steinbacher, M., Dommen, J., Prevot, A. S. H., Fisseha, R., Weingartner, E., Frankevich, V., Zenobi, R., and Baltensperger, U.: Identification of polymers as major components of atmospheric organic aerosols, Science, 303, 1659-1662, doi:10.1126/science.1092185, 2004.

Kanakidou, M., Seinfeld, J. H., Pandis, S. N., Barnes, I., Dentener, F. J., Facchini, M. C., Van Dingenen, R., Ervens, B., Nenes, A., Nielsen, C. J., Swietlicki, E., Putaud, J. P., Balkanski, Y., Fuzzi, S., Horth, J., Moortgat, G. K., Winterhalter, R., Myhre, C. E. L., Tsigaridis, K., Vignati, E., Stephanou, E. G., and Wilson, J.: Organic aerosol and global climate modelling: a review, Atmos. Chem. Phys., 5, 1053-1123, doi:10.5194/acp-5-1053-2005, 2005.

Kang, E., Root, M. J., Toohey, D. W., and Brune, W. H.: Introducing the concept of Potential Aerosol Mass (PAM), Atmos. Chem. Phys., 7, 5727-5744, doi:10.5194/acp-7-5727-2007, 2007.

Kim, H. and Paulson, S. E.: Real refractive indices and volatility of secondary organic aerosol generated from photooxidation and ozonolysis of limonene, $\alpha$-pinene and toluene, Atmos. Chem. Phys., 13, 7711-7723, doi:10.5194/acp-13-7711-2013, 2013.

Kim, H., Barkey, B., and Paulson, S. E.: Real refractive indices and formation yields of secondary organic aerosol generated from photooxidation of limonene and $\alpha$-pinene: the effect of the $\mathrm{HC} / \mathrm{NO}_{\mathrm{x}}$ ratio, J. Phys. Chem. A, 116, 6059-6067, doi:10.1021/jp301302z, 2012.

Kim, H., Liu, S., Russell, L. M., and Paulson, S. E.: Dependence of real refractive indices on O:C, H:C and mass fragments of secondary organic aerosol generated from ozonolysis and photooxidation of limonene and $\alpha$-pinene, Aerosol Sci. Tech., 48, 498-507, doi:10.1080/02786826.2014.893278, 2014.

Kirchstetter, T. W., Novakov, T., and Hobbs, P. V.: Evidence that the spectral dependence of light absorption by aerosols is affected by organic carbon, J. Geophys. Res., 109, D21208, doi:10.1029/2004jd004999, 2004.

Kleeman, M. J., Schauer, J. J., and Cass, G. R.: Size and composition distribution of fine particulate matter emitted from motor vehicles, Environ. Sci. Technol., 34, 1132-1142, doi:10.1021/es981276y, 2000.

Kroll, J. H. and Seinfeld, J. H.: Chemistry of secondary organic aerosol: Formation and evolution of low-volatility organics in the atmosphere, Atmos. Environ., 42, 3593-3624, doi:10.1016/j.atmosenv.2008.01.003, 2008.

Lack, D. A., Bahreini, R., Langridge, J. M., Gilman, J. B., and Middlebrook, A. M.: Brown carbon absorption linked to organic mass tracers in biomass burning particles, Atmos. Chem. Phys., 13, 2415-2422, doi:10.5194/acp-13-2415-2013, 2013.
Lambe, A. T., Ahern, A. T., Williams, L. R., Slowik, J. G., Wong, J. P. S., Abbatt, J. P. D., Brune, W. H., Ng, N. L., Wright, J. P., Croasdale, D. R., Worsnop, D. R., Davidovits, P., and Onasch, T. B.: Characterization of aerosol photooxidation flow reactors: heterogeneous oxidation, secondary organic aerosol formation and cloud condensation nuclei activity measurements, Atmos. Meas. Tech., 4, 445-461, doi:10.5194/amt-4-445-2011, 2011.

Lambe, A. T., Cappa, C. D., Massoli, P., Onasch, T. B., Forestieri, S. D., Martin, A. T., Cummings, M. J., Croasdale, D. R., Brune, W. H., Worsnop, D. R., and Davidovits, P.: Relationship between oxidation level and optical properties of secondary organic aerosol, Environ. Sci. Technol., 47, 6349-6357, doi:10.1021/es401043j, 2013.

Laskin, J., Laskin, A., Roach, P. J., Slysz, G. W., Anderson, G. A., Nizkorodov, S. A., Bones, D. L., and Nguyen, L. Q.: Highresolution desorption electrospray ionization mass spectrometry for chemical characterization of organic aerosols, Anal. Chem., 82, 2048-2058, doi:10.1021/ac902801f, 2010.

Li, K., Wang, W., Ge, M., Li, J., and Wang, D.: Optical properties of secondary organic aerosols generated by photooxidation of aromatic hydrocarbons, Sci. Rep., 4, 4922, doi:10.1038/srep04922, 2014.

Lim, Y. B., Tan, Y., Perri, M. J., Seitzinger, S. P., and Turpin, B. J.: Aqueous chemistry and its role in secondary organic aerosol (SOA) formation, Atmos. Chem. Phys., 10, 1052110539, doi:10.5194/acp-10-10521-2010, 2010.

Liu, P. F., Zhang, Y., and Martin, S. T.: Complex refractive indices of thin films of secondary organic materials by spectroscopic ellipsometry from 220 to $1200 \mathrm{~nm}$, Environ. Sci. Technol., 47, 13594-13601, doi:10.1021/es403411e, 2013.

Liu, S., Shilling, J. E., Song, C., Hiranuma, N., Zaveri, R. A., and Russell, L. M.: Hydrolysis of organonitrate functional groups in aerosol particles, Aerosol Sci. Tech., 46, 1359-1369, doi:10.1080/02786826.2012.716175, 2012.

Loeffler, K. W., Koehler, C. A., Paul, N. M., and De Haan, D. O.: Oligomer formation in evaporating aqueous glyoxal and methyl glyoxal solutions, Environ. Sci. Technol., 40, 6318-6323, doi:10.1021/es060810w, 2006.

Martin, R. V., Jacob, D. J., Yantosca, R. M., Chin, M., and Ginoux, P.: Global and regional decreases in tropospheric oxidants from photochemical effects of aerosols, J. Geophys. Res.- Atmos., 108, 4097, doi:10.1029/2002jd002622, 2003.

Nakayama, T., Matsumi, Y., Sato, K., Imamura, T., Yamazaki, A., and Uchiyama, A.: Laboratory studies on optical properties of secondary organic aerosols generated during the photooxidation of toluene and the ozonolysis of $\alpha$-pinene, J. Geophys. Res., 115, D24204, doi:10.1029/2010jd014387, 2010.

Nakayama, T., Sato, K., Matsumi, Y., Imamura, T., Yamazaki, A., and Uchiyama, A.: Wavelength and $\mathrm{NO}_{\mathrm{x}}$ dependent complex refractive index of SOAs generated from the photooxidation of toluene, Atmos. Chem. Phys., 13, 531-545, doi:10.5194/acp-13531-2013, 2013.

Ng, N. L., Kroll, J. H., Chan, A. W. H., Chhabra, P. S., Flagan, R. C., and Seinfeld, J. H.: Secondary organic aerosol formation from $m$-Xylene, toluene, and benzene, Atmos. Chem. Phys., 7, 3909-3922, doi:10.5194/acp-7-3909-2007, 2007.

Odum, J. R., Hoffmann, T., Bowman, F., Collins, D., Flagan, R. C., and Seinfeld, J. H.: Gas/particle partitioning and secondary 
organic aerosol yields, Environ. Sci. Technol., 30, 2580-2585, doi:10.1021/es950943+, 1996.

Odum, J. R., Jungkamp, T. P. W., Griffin, R. J., Flagan, R. C., and Seinfeld, J. H.: The atmospheric aerosol-forming potential of whole gasoline vapor, Science, 276, 96-99, doi:10.1126/science.276.5309.96, 1997.

Ofner, J., Krüger, H.-U., Grothe, H., Schmitt-Kopplin, P., Whitmore, K., and Zetzsch, C.: Physico-chemical characterization of SOA derived from catechol and guaiacol - a model substance for the aromatic fraction of atmospheric HULIS, Atmos. Chem. Phys., 11, 1-15, doi:10.5194/acp-11-1-2011, 2011.

Ramana, M. V., Ramanathan, V., Feng, Y., Yoon, S. C., Kim, S. W., Carmichael, G. R., and Schauer, J. J.: Warming influenced by the ratio of black carbon to sulphate and the black-carbon source, Nat. Geosci., 3, 542-545, doi:10.1038/ngeo918, 2010.

Ran, L., Zhao, C. S., Xu, W. Y., Han, M., Lu, X. Q., Han, S. Q., Lin, W. L., Xu, X. B., Gao, W., Yu, Q., Geng, F. H., Ma, N., Deng, Z. Z., and Chen, J.: Ozone production in summer in the megacities of Tianjin and Shanghai, China: a comparative study, Atmos. Chem. Phys., 12, 7531-7542, doi:10.5194/acp-12-75312012, 2012.

Roberts, J. M.: The atmospheric chemistry of organic nitrates, Atmos. Environ., 24, 243-287, doi:10.1016/0960-1686(90)90108Y, 1990.

Russell, L. M., Bahadur, R., Hawkins, L. N., Allan, J., Baumgardner, D., Quinn, P. K., and Bates, T. S.: Organic aerosol characterization by complementary measurements of chemical bonds and molecular fragments, Atmos. Environ., 43, 61006105, doi:10.1016/j.atmosenv.2009.09.036, 2009a.

Russell, L. M., Takahama, S., Liu, S., Hawkins, L. N., Covert, D. S., Quinn, P. K., and Bates, T. S.: Oxygenated fraction and mass of organic aerosol from direct emission and atmospheric processing measured on the R/V Ronald Brown during TEXAQS/GoMACCS 2006, J. Geophys. Res.-Atmos., 114, D00F05, doi:10.1029/2008jd011275, 2009b.

Russell, L. M., Bahadur, R., and Ziemann, P. J.: Identifying organic aerosol sources by comparing functional group composition in chamber and atmospheric particles, P. Natl. Acad. Sci. USA, 108, 3516-3521, doi:10.1073/pnas.1006461108, 2011.

Sato, K., Hatakeyama, S., and Imamura, T.: Secondary organic aerosol formation during the photooxidation of toluene: $\mathrm{NO}_{\mathrm{x}}$ dependence of chemical composition, J. Phys. Chem. A, 111, 9796-9808, doi:10.1021/jp071419f, 2007.

Shapiro, E. L., Szprengiel, J., Sareen, N., Jen, C. N., Giordano, M. R., and McNeill, V. F.: Light-absorbing secondary organic material formed by glyoxal in aqueous aerosol mimics, Atmos. Chem. Phys., 9, 2289-2300, doi:10.5194/acp-9-2289-2009, 2009.

Shilling, J. E., Chen, Q., King, S. M., Rosenoern, T., Kroll, J. H., Worsnop, D. R., DeCarlo, P. F., Aiken, A. C., Sueper, D., Jimenez, J. L., and Martin, S. T.: Loading-dependent elemental composition of $\alpha$-pinene SOA particles, Atmos. Chem. Phys., 9, 771-782, doi:10.5194/acp-9-771-2009, 2009.

Sun, H., Biedermann, L., and Bond, T. C.: Color of brown carbon: A model for ultraviolet and visible light absorption by organic carbon aerosol, Geophys. Res. Lett., 34, L17813, doi:10.1029/2007g1029797, 2007.

Takahama, S., Johnson, A., and Russell, L. M.: Quantification of carboxylic and carbonyl functional groups in organic aerosol infrared absorbance spectra, Aerosol Sci. Tech., 47, 310-325, doi:10.1080/02786826.2012.752065, 2012.

Tie, X., Madronich, S., Walters, S., Zhang, R., Rasch, P., and Collins, W.: Effect of clouds on photolysis and oxidants in the troposphere, J. Geophys. Res., 108, 4642, doi:10.1029/2003jd003659, 2003.

Toon, O. B., Pollack, J. B., and Khare, B. N.: The optical constants of several atmospheric aerosol species: Ammonium sulfate, aluminum oxide, and sodium chloride, J. Geophys. Res., 81, 57335748, doi:10.1029/JC081i033p05733, 1976.

Turpin, B. J., Huntzicker, J. J., Larson, S. M., and Cass, G. R.: Los Angeles summer midday particulate carbon: primary and secondary aerosol, Environ. Sci. Technol., 25, 1788-1793, doi:10.1021/es00022a017, 1991.

Updyke, K. M., Nguyen, T. B., and Nizkorodov, S. A.: Formation of brown carbon via reactions of ammonia with secondary organic aerosols from biogenic and anthropogenic precursors, Atmos. Environ., 63, 22-31, doi:10.1016/j.atmosenv.2012.09.012, 2012.

Volkamer, R., Jimenez, J. L., San Martini, F., Dzepina, K., Zhang, Q., Salcedo, D., Molina, L. T., Worsnop, D. R., and Molina, M. J.: Secondary organic aerosol formation from anthropogenic air pollution: Rapid and higher than expected, Geophys. Res. Lett., 33, L17811, doi:10.1029/2006GL026899, 2006.

Wu, Z., Hu, M., Lin, P., Liu, S., Wehner, B., and Wiedensohler, A.: Particle number size distribution in the urban atmosphere of Beijing, China, Atmos. Environ., 42, 7967-7980, doi:10.1016/j.atmosenv.2008.06.022, 2008.

Zarzana, K. J., De Haan, D. O., Freedman, M. A., Hasenkopf, C. A., and Tolbert, M. A.: Optical properties of the products of $\alpha$-dicarbonyl and amine reactions in simulated cloud droplets, Environ. Sci. Technol., 46, 4845-4851, doi:10.1021/es2040152, 2012.

Zhang, X., Lin, Y.-H., Surratt, J. D., Zotter, P., Prevot, A. S. H., and Weber, R. J.: Light-absorbing soluble organic aerosol in Los Angeles and Atlanta: A contrast in secondary organic aerosol, Geophys. Res. Lett., 38, L21810, doi:10.1029/2011GL049385, 2011.

Zhang, X., Lin, Y.-H., Surratt, J. D., and Weber, R. J.: Sources, composition and absorption Ångström exponent of lightabsorbing organic components in aerosol extracts from the Los Angeles basin, Environ. Sci. Technol., 47, 3685-3693, doi:10.1021/es305047b, 2013.

Zhang, X., Cappa, C. D., Jathar, S. H., McVay, R. C., Ensberg, J. J., Kleeman, M. J., and Seinfeld, J. H.: Influence of vapor wall loss in laboratory chambers on yields of secondary organic aerosol, P. Natl. Acad. Sci. USA., 111, 5802-5807, doi:10.1073/pnas.1404727111, 2014.

Zhong, M. and Jang, M.: Light absorption coefficient measurement of SOA using a UV-Visible spectrometer connected with an integrating sphere, Atmos. Environ., 45, 4263-4271, doi:10.1016/j.atmosenv.2011.04.082, 2011.

Zhong, M., Jang, M., Oliferenko, A., Pillai, G. G., and Katritzky, A. R.: The SOA formation model combined with semiempirical quantum chemistry for predicting UV-Vis absorption of secondary organic aerosols, Phys. Chem. Chem. Phys., 14, 90589066, doi:10.1039/c2cp23906j, 2012. 